\title{
The Power of Supplements Material of Seagrass Ecology on Student Worksheets to Improve Scientific Literacy of Junior High School Students in Coastal Village, East Lombok
}

\author{
Abdul Syukur ${ }^{1,2, *}$, Lalu Zulkifli ${ }^{1,2}$, Mahrus ${ }^{1,2}$ \\ ${ }^{1}$ Department of Sciences Education, ${ }^{2}$ Department of \\ Biological Sciences Education \\ ${ }_{1,2}^{1,2}$ Mataram University \\ 1,2 Mataram, Indonesia \\ *syukurbiologi@unram.ac.id
}

\author{
Kumala Ratna Dewi \\ Department of Sciences Education \\ Mataram University \\ Mataram, Indonesia
}

\begin{abstract}
Environmental characteristics in coastal areas are receiving less attention, especially for science education development. However, it provides relevant learning objectives, such as the presence of seagrass and marine aquaculture. This study aimed to assess the contribution of student worksheets (synthesis of seagrass ecology and marine aquaculture values) in increasing students' scientific literacy. The method used is quasi experiment with pre-post-test design, followed up by the learning observation to strengthen the quantitative data. Data were analysed on using simple statistical analysis. The results showed that all students knew seagrass and marine aquaculture. Furthermore, the post-test results show that the average value of the control students is lower than the average grade of the experimental class. Meanwhile, student from the experimental classroom shows more innovative in completing project-based learning tasks. It is relevant to students who understand seagrass and marine culture, where they interact after returning from school. This research concludes that the of student worksheets material based on local indigenous value played role in enhancing students' scientific literacy. Besides, the short essay on science and its values can replace the role of science teaching material that still rarely provided by teachers/schools.
\end{abstract}

Keywords-material learning supplements, seagrass ecology, student worksheets, scientific literacy

\section{INTRODUCTION}

Seagrass areas in East Lombok's coastal waters are scattered along the mainland coastal waters of Lombok Island and small islands. The total area of seagrass in the southern part of East Lombok, which is around the waters of Tanjung Luar, is 264.60 ha and found 118 fish species associated with seagrass [1]. Also, in waters with seagrass areas, such as in Lombok's southern coastal waters, there is a diversity of marine biota species such as bivalves and echinoderms [2]. Another potential of East Lombok's coastal water is the marine environment, the bay's waters, and has been used by the community to develop aquatic cultivation. In this regard, seagrass's ecological services are a location for taking seeds for cultivation, such as economically important fish and cuttlefish $[3,4]$. The strategic values of marine cultivation practices by the community are: (1) protection from exploitation of resources such as seagrass ecosystems, (2) small-scale fishers have alternative livelihoods, (3) increase the participation of fishers and local communities in protecting local scale seagrass and (4) raise awareness of the importance of togetherness's value to create a sense of security and comfort in people's social lives [4].

Local natural resources such as seagrass beds and marine culture are relevant learning resources to be developed, especially for contextual learning development. The two are learning objects (marine cultivation and seagrass ecosystem services) above can be extracted into relevant teaching materials at each level of education. Furthermore, the extract of results has been using for the development of teaching materials [5]. It is necessary because the extraction of teaching materials from the local environment has benefits including (1) local materials can be a cognitive bridge between abstraction and the realities of daily life of students (2) sources of teaching materials from the local environment enable teachers and students thinking has the initial cognitive similarity to be developed at a higher cognitive level, (3) local materials are present as a substitute for rare and expensive teaching materials (4) local materials can save costs, (5) local materials contribute to the achievement of educational goals because provide opportunities to develop scientific skills, attitudes, and practical skills and (6) local materials to some extent fill the gaps or absence of learning resources [6,7]. The concept of learning base on the local environment can be synthesis in Student worksheets. Also, local potential-based learning is quite effective in improving students' generic skills [8]. In this 
regard, environmental innovation-based science student worksheets significantly increase students' critical thinking power and scientific attitude in junior high schools [9]. However, students' obstacles are discovering new scientific explanations for findings that are classifying into several components, including a lack of initial knowledge, barriers to complex material structures, and failure of creative cognitive processes [10].

The curriculum 2013 has the same challenges expected in scientific literacy, facing the rapid advancement of the times and various problems related to environmental issues, advances in technology and information, the rise of creative and cultural industries, and education development. A guided inquiry learning model can have applied to learn to improve students' scientific literacy skills. It is based on previous research results to enhance students' scientific literacy skills and enhance the learning process. Guided inquiry-based teaching materials so that students are expecting to achieve optimal competence [11]. The presence of student worksheets is quite relevant to the scientific learning model because it can facilitate student creativity to find a concept and develop various scientific skills to overcome student learning barriers [12]. The preliminary observations about it were that student worksheets in junior high schools in the study location only used student worksheets that did not come from the environment. Therefore, research was conducted to study the impact of arranging essay in student worksheets based on the surrounding environment, seagrass ecosystem services and marine cultivation, to improve students' scientific literacy.

\section{MATERIAL AND METHODS}

This research has been conducting in the odd semester of the 2020/2021 school year, at the Pantai Desa Junior High School in East Lombok Regency. The design used in the research was a quasi-experimental (Quasi Experiment) by applying student worksheets guided inquiry model based on marine cultivation in the experimental class and conventional student worksheets in the control class. The population of this study was all schools in the research location. The design used in this study is the non-equivalent pre-test-post-test control group design the data collection of scientific literacy skills using carried out test instrument, namely a multiple-choice type test. The data from the pre-test and post-test in tabular form for interpretation purposes. The mean, standard deviation, and difference of mean for each group at each school. The significance of the difference between the mean scores of the two experimental and control groups on the pre-test score variable, the post-test score at the significance level of 0.05 , was carried out through the Independent sample T-test using SPSS 17.003.

\section{RESULTS AND DISCUSSION}

Research on the development of supplement materials from seagrass ecology as material for guided inquiry-based written in student worksheets aims to improve junior high school students' scientific literacy in coastal areas, East Lombok.
Before the student worksheets are using, an expert lecturer should first assess the student worksheets feasibility. Feasibility validation is carried out so that the product being developed is valid when it is tested extensively. The results of the media expert validation are as follows in (Table 1, 2,3)

TABLE I. RESULTS OF EXPERT ASSESSMENT

\begin{tabular}{|l|l|l|l|l|}
\hline No & \multicolumn{1}{|c|}{ Aspect Score } & Score & Value & Category \\
\hline 1 & Language & 3,5 & A & Very goodk \\
\hline 2 & Characteristics Student & 4 & A & Very good \\
\hline 3 & $\begin{array}{l}\text { Complete } \\
\text { Worksheets Format }\end{array}$ & A & Very good \\
\hline 4 & Presentation & 3,5 & A & Very good \\
\hline 5 & Technical Usage & 3 & B & good \\
\hline & Average & & A & Very good \\
\hline
\end{tabular}

TABLE II. MATERIAL EXPERT VALIDATION ASSESSMENT

\begin{tabular}{|l|l|l|l|l|}
\hline No & Aspect Score & Score & Value & Category \\
\hline 1 & Content eligibility & 3,7 & A & Very good \\
\hline 2 & Language & 4 & A & Very good \\
\hline 3 & Characteristics & 4 & A & Very good \\
\hline & Average & & & Very good \\
\hline
\end{tabular}

TABLE III. ASSESSMENT OF PRACTICALITy By the TEACHER

\begin{tabular}{|l|l|l|l|l|}
\hline No & \multicolumn{1}{|c|}{ Aspect Score } & Score & Value & Category \\
\hline 1 & Language & 4 & A & Very good \\
\hline 2 & Characteristics & 3,5 & A & Very good \\
\hline 3 & $\begin{array}{l}\text { Complete Student } \\
\text { Worksheets Format }\end{array}$ & 3,8 & A & Very good \\
\hline 4 & Presentation & 3,5 & A & Very good \\
\hline 5 & Technical Usage & $3,6^{\text {a }}$ & A & Very good \\
\hline & Average & & A & Very good \\
\hline
\end{tabular}

Besides, the declared are valid; the product developed is also displayed practical as assessed in Table 3, with a perfect category. The advice given by the teacher is to detail work steps so that students can easily use them. Student worksheets have gone through the validation stage and have been revised according to the validator's input. Then student worksheets were applied to students in 3 junior high schools in the coastal area of Lombok Timu, namely SMP 4 Jerowaru, SMP 1 Labuhab Haji, and SMP 1 Keruak. The student worksheets test was carried out by learning using the student worksheets based on seagrass ecology in the experimental class and the student worksheets used by teachers for the control class. Learning begins with a pre-test then ends with a post-test to measure scientific literacy skills. Scientific literacy can be interpreted as the ability to understand the scientific process and engage with scientific information in everyday life [13].

Meanwhile, "scientific literacy" explains that the main component of scientific literacy is understanding science content, namely the basic science concepts. The second group of "scientific literacy" views scientific literacy as a requirement to adapt to the challenges of a rapidly changing world [14]. The pre-test and post-test results in control, and experimental classes were used to determine Student Worksheets' effectiveness to improve students' scientific literacy skills. The 
pre-test and post-test results in the practical class and control class in 3 schools in the coastal area of East Lombok are as follows in Figure 1.

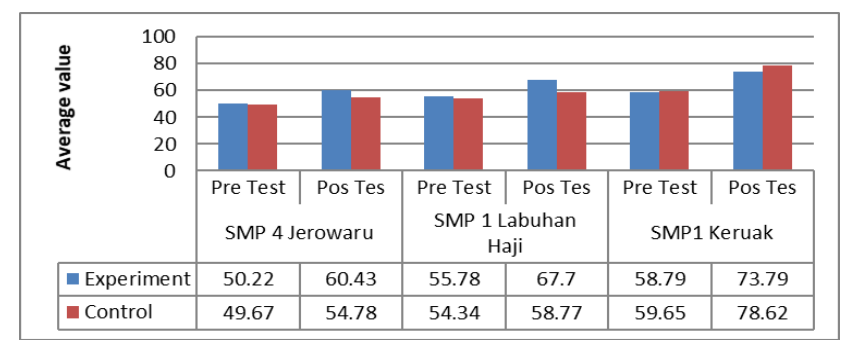

Fig. 1. Pre-test and post-test results of science literacy ability.
The assessment of students' scientific literacy abilities shows that when the initial average pre-test results show an almost identical value, the two classes used for research are practically equal. However, after being given different treatments, the average post-test results of the two types have differences, where the practical level is superior to the control class. It is shows that the use of student worksheets IPA as a learning supplement that uses the ecology of seagrass can improve students' scientific literacy skills. The result (Table 4) of data analysis of scientific literacy skills in this study used the Independent Sample T-test with the SPSS 17.0 program's help at the $5 \%$ significance level.

TABLE IV. RESUlts OF THE INDEPENDENT SAMPLE T-TEST ANALYSIS

\begin{tabular}{|c|c|c|c|c|c|c|c|}
\hline Name of School & \multicolumn{2}{|c|}{ Kelas } & $\mathbf{t}$ & df & Sig. (2-tailed) & Mean Difference & Std. Error Difference \\
\hline \multirow[t]{2}{*}{ SMP 4 Jerowaru } & Experiment & Pre-Test & -4.733 & 61 & 0.000 & -10.938 & 2.263 \\
\hline & Control & Pre-Test & -9.164 & 56 & 0.000 & -25.517 & 2.815 \\
\hline \multirow[t]{3}{*}{ SMP 1 Labuhan Haji } & \multirow[t]{2}{*}{ Experiment } & Pre-Test & -4.633 & 62 & 0.000 & -10.938 & 2.263 \\
\hline & & Pos Tes & -4.633 & 53.314 & 0.000 & -10.938 & 2.263 \\
\hline & Control & Pre-Test & -5.347 & 56 & 0.000 & -11.207 & 1.985 \\
\hline \multirow[t]{4}{*}{ SMP 1 Keruak } & \multirow[t]{2}{*}{ Experiment } & Pre-Test & -8.856 & 56 & 0.000 & -18.966 & 2.118 \\
\hline & & Pos Tes & -8.856 & 53.095 & 0.000 & -18.966 & 2.118 \\
\hline & \multirow[t]{2}{*}{ Control } & Pre-Test & -6.732 & 56 & 0.000 & -15.000 & 2.224 \\
\hline & & Pos Tes & -6.732 & 55.9784 & 0.000 & -15.000 & 2.224 \\
\hline
\end{tabular}

The activity stages use IPA student worksheets that take advantage of seagrass ecology as a learning supplement, starting with connecting their initial knowledge with the material to be studied. The last is the extended stage, where students connect and analyse the relationship between the concepts learned and seagrass's ecological concepts. The discovery and advancement of science and technology can never be separated from the role of science. Science Literacy is one of the areas of PISA (Program for International Student Assessment), which focuses on a person's ability to use scientific knowledge and skills in making decisions and solving problems. Scientific literacy is an individual's scientific knowledge and the capacity to use that knowledge to identify questions, acquire new knowledge, explain scientific phenomena, and draw evidence-based conclusions about issues related to science [15]. A study on the level of scientific literacy of secondary students conducted by the OECD in 2015 shows that Indonesia's student literacy group is still low. However, the point has increased from a study conducted in 2012.

\section{CONCLUSION}

Student worksheets are vital to assist the learning process of students. The material sourced from seagrass ecology material can supplement students' scientific literacy skills in schools in the research location. Therefore, a more comprehensive teacher's cognitive abilities are needed to take advantage of the environment's potential in helping students' learning process. Also, the utilization of the surrounding environment's potential can increase awareness of preserving the environment through formal education.

\section{ACKNOWLEDGMENTS}

The author thanks the Rektor Mataram for providing funds to carry out this research.

\section{REFERENCES}

[1] A. Syukur, Y. Wardiatno, I. Muchsin and M.M. Kamal, "Threats to seagrass ecology and indicators of the importance of seagrass ecological services in the coastal waters of East Lombok, Indonesia," American Journal of Environmental Sciences, vol. 13, no. 3, pp. 251-265, 2017.

[2] A. Syukur, A. Al-Idrus and L. Zulkifli, "Ecotourism development based on the diversity of echinoderms species in seagrass beds on the south coastal of Lombok island, Indonesia," Journal of Environmental Science and Technology, vol. 13, no. 2, pp. 57-68, 2020.

[3] A. Syukur and S.A. Mahrus, The potential assessment environment friendly aquaculture of small-scale fishermen as a conservation strategy seagrass beds in coastal areas of Tanjung Luar East Lombok, Indonesia," Management, vol. 19, no. 20, pp. 21, 2016.

[4] A. Syukur and S.A. Mahrus, The Perspective of Small Fisherman toward the Seagrass Conservation Values for the Sustainability of Friendly Environmental Fish Farming: a Case Study in Coastal Waters of East Lombok, 2018 
[5] E. Güclüer and T. Kesercioğlu, "The Effect of Using Activities Improving Scientific Literacy on Students' achievement In Science and Technology Lesson,” International Online Journal of Primary Education (IOJPE) ISSN: 1300-915X, vol. 1, pp. 1-12, 2012.

[6] A. Keselman, "Supporting inquiry learning by promoting normative understanding of multivariable causality," Journal of Research in Science Teaching, vol. 40, no. 9, pp. 898-921, 2003.

[7] H.S. Lin, Z.R. Hong and T.C. Huang, "The role of emotional factors in building public scientific literacy and engagement with science," International Journal of Science Education, vol. 34, no. 1, pp. 25-42, 2012.

[8] M. Pedaste, M. Mäeots, L.A. Siiman, T. De Jong, S.A. Van Riesen, E.T. Kamp and E. Tsourlidaki, "Phases of inquiry-based learning: Definitions and the inquiry cycle," Educational research review, vol. 14, pp. 47-61, 2015.

[9] W.S. Utami, "The Effectiveness of Geography Student Worksheet to Develop Learning Experiences for High School Students," Journal of Education and Learning, vol. 5, no. 3, pp. 315-321, 2016
[10] M. Misbah, D. Dewantara, S.M. Hasan and S. Annur, "The development of student worksheet by using Guided Inquiry Learning Model to train student's scientific attitude," Unnes Science Education Journal, vol. 7 , no. 1,2018

[11] R.R. Sari and K. Abdurrahman, "Development and Validation of students' Worksheet Based on Guided-Inquiry to Improve Students' Scientific Literacy Skills of Junior High School on Straight Motion Concept," JPhCS, vol. 1467, no. 1, pp. 012073, 2020.

[12] H. Fives, W. Huebner, A.S. Birnbaum and M. Nicolich, "Developing a measure of scientific literacy for middle school students," Science Education, vol. 98, no. 4, pp. 549-580, 2014.

[13] B. Utami, S. Saputro, A. Ashadi and M. Masykuri, Scientific literacy in science lesson. In International Conference on Teacher Training and Education. Sebelas Maret University, 2016.

[14] OECD, PISA 2012 Results in Focus What 15-Year-Olds Know and What They Can Do with What They Know. Paris: PISA OECD Publishing., 2014.

[15] OECD, PISA 2015 result in focus. Paris: PISA OECD Publishing, 2016. 